\title{
The metabolism of palmitic, stearic, oleic and linoleic acids in broiler chickens
}

\author{
By JENNIFER M. INFIELD AND E. F. ANNISON \\ Unilever Research Laboratory Colworth/Welwyn, \\ Colworth House, Sharnbrook, Bedford
}

(Received 30 fanuary $1973-$ Accepted 6 fune 1973)

\begin{abstract}
1. Interrelationships between the level of dietary fat and the metabolism of palmitate, stearate, oleate and linoleate in the broiler chicken have been studied by means of isotope dilution techniques.

2. The composition of the free fatty acid (FFA) and triglyceride fractions of plasma lipids was influenced by the level of dietary fat, but the only effect of diet on plasma concentration was the higher FFA levels after feeding in birds given the high-fat diet.

3. The rates of entry and oxidation of the individual fatty acids were correlated with their concentrations in plasma, but were unrelated to the level of dietary fat. Slight differences in the metabolism of the individual fatty acids were observed.

4. Acetyl-CoA carboxylase $(E C 6.4,1.2)$ and desaturase activities were higher in the livers of birds given the low-fat diet.
\end{abstract}

Quantitative information on the interrelationships of the level of dietary fat and fatty acid metabolism in the chicken is scanty, in spite of the increased use of fat in commercial rations to provide diets of high nutrient content for broiler chickens. In the present studies isotope dilution techniques were used to measure the rates of entry and oxidation of palmitic, stearic, oleic and linoleic acids in broilers starved $(48 \mathrm{~h})$ or given either a low-fat or a high-fat diet. The influence of the level of dietary fat on lipogenesis was studied using acetyl-CoA carboxylase (EC 6.4.1.2) activity in liver tissue as an index of the capacity of the bird to synthesize fat, as in the avian the liver is the main site of lipogenesis (see Annison, 1971). Acetyl-CoA carboxylase has been used as an index of the rate of lipogenesis in rats (Bortz, Abraham \& Chaikoff, I963), pigeons (Goodridge \& Ball, 1966) and laying hens (Balnave \& Pearce, I969).

The reported inverse relationship between the level of dietary fat and desaturase activity in the rat (Inkpen, Harris \& Quakenbush, 1969) prompted a study of desaturase activity in the liver of birds fed on low-fat or high-fat diets.

\section{MATERIALS AND METHODS}

\section{Experimental animals}

Male Cobb broilers were individually housed and fed from 4 weeks of age on either a low-fat $(20 \mathrm{~g} / \mathrm{kg})$ mash diet, or the same diet containing added soya-bean oil to raise the fat content to $102 \mathrm{~g} / \mathrm{kg}$. The composition of the diets is shown in Table I, and their fatty acid composition in Table 2. Equal amounts of metabolizable energy were given, the intake $a d l i b$. of the birds fed on the low-fat diet being used to define the intake of the high-fat diet. The birds used for experimentation in vivo and for 
Table I. Composition $(\mathrm{g} / \mathrm{kg})$ of chick diets

Ingredient

Wheat meal

Soya-bean meal

White-fish meal (extracted)

Casein

DL-Methionine

Minerals*

Vitamins $†$

Sodium chloride

Calcium hydrogen orthophosphate

Soya-bean oil

Santoquin (Monsanto Chemicals)

Maize starch

$\begin{array}{rr}\begin{array}{c}\text { Low-fat } \\ \text { diet }\end{array} & \begin{array}{c}\text { High-fat } \\ \text { diet }\end{array} \\ 170.0 & 189.6 \\ 130 \cdot 1 & 145 \cdot 1 \\ 70 \cdot 1 & 78 \cdot 2 \\ 80.0 & 89 \cdot 0 \\ 1.0 & 1 \cdot 1 \\ 16.7 & 18.6 \\ 20.0 & 22.3 \\ 4.0 & 4.5 \\ 25.0 & 27.8 \\ 5.0 & 85.6 \\ 0.2 & 0.2 \\ 477.9 & 338.0\end{array}$

* Contained $(\mathrm{mg} / \mathrm{kg})$ : manganese sulphate 650 , cobalt sulphate $\mathrm{I}$, copper sulphate 20 , zinc carbonate Ioo, sodium molybdate 9 , ferric citrate 499 , sodium selenate $0 \cdot 2$, boric acid 9 , potassium iodate 40 , magnesium sulphate 3496 , potassium hydrogen phosphate 8989 , sodium chloride 3996 .

† Contained $(\mathrm{mg} / \mathrm{kg})$ : vitamin A (50000 i.u. $/ \mathrm{g})$ 200, vitamin $\mathrm{D}_{3}$ (10000 i.u. $/ \mathrm{g}$ ) 200, vitamin $\mathrm{E}$ $(52.5 \mathrm{i.u} / \mathrm{g}) 200$, thiamin hydrochloride 100 , choline chloride $(25 \%) 8000$, vitamin $\mathrm{B}_{12}(770 \mathrm{mg} / \mathrm{kg}) 26$, riboflavin I5, calcium D-pantothenate 20 , folic acid 4, nicotinic acid 100 , pyridoxine hydrochloride 6 , ascorbic acid 250 , vitamin $\mathrm{K}_{5}$, biotin 4 , maize starch 1470 .

\section{Table 2. Fatty acid content $(\mathrm{g} / \mathrm{kg})$ of chick diets}

$\begin{array}{lcc}\text { Acid* } & \text { Low-fat diet } & \text { High-fat diet } \\ \text { I0:0 } & 0.2 & 0.0 \\ \text { 12:0 } & 0.5 & 0.1 \\ \text { 13:0 } & 3.2 & 0.0 \\ \text { 14:0 } & 0.3 & 0.5 \\ \text { I 5:0 } & 0.5 & 0.0 \\ \text { I6:0 } & 38.1 & 13.1 \\ \text { I6: } & 3.3 & 0.3 \\ \text { I7:0 } & 0.4 & 0.0 \\ \text { I8:0 } & 8.6 & 3.9 \\ \text { I8:1 } & 43.1 & 22.9 \\ \text { I8:2 } & 90.4 & 53.3 \\ \text { I8:3 } & 11.4 & 7.9 \\ \text { Lipid }(\%) & 2.00 & 10.2\end{array}$

* Nomenclature according to Farquhar, Insull, Rosen, Stoffel \& Ahrens (1959).

the supply of tissues for studies in vitro were aged 8-9 weeks, and weighed $\mathrm{I}_{4}{ }^{-}$ $2 \cdot 0 \mathrm{~kg}$. Plasma FFA and triglyceride values were obtained from ten fed and ten starved $(48 \mathrm{~h})$ chicks fed on the high-fat diet and from nine fed and eight starved $(48 \mathrm{~h})$ chicks fed on the low-fat diet.

\section{Measurement of fatty-acid entry rates}

Polyethylene catheters (Portex; Portland Plastics Ltd, UK) of bore size 0.4 and $0.5^{8} \mathrm{~mm}$ were inserted into the basilic vein and brachial artery respectively of one wing under local anaesthesia, and kept filled with heparinized saline $(9 \mathrm{~g} / 1,500$ units heparin $/ \mathrm{ml}$ ). The bird, prepared with catheters at least $\mathrm{I} 6 \mathrm{~h}$ earlier, was placed in a clear, sealed Perspex box $(5 \mathrm{ro} \times 470 \times 240 \mathrm{~mm})$. The catheters were led from the box 
through a rubber seal, and a solution of ${ }^{14} \mathrm{C}$-labelled palmitic, stearic, oleic or linoleic acid $(\mathrm{I} \cdot 25 \mu \mathrm{g} ; 40 \mu \mathrm{g} / \mathrm{ml}$ ) bound to albumin (Bovine Albumin Fraction V; Sigma Chemical Co.) by the method of Laurell (1957) was infused intravenously at $0.04 \mathrm{ml} /$ $\min$ for $5 \mathrm{~h}$. Carbon dioxide production was measured and recorded with a Noyons diaferometer (Kipp and Zonen, Delft, Netherlands) which was used to draw air through the box at $8 \mathrm{l} / \mathrm{min}$. This flow-rate was adequate to prevent more than a slight increase $\left(\mathrm{I}^{\circ}\right)$ above room temperature $\left(20-22^{\circ}\right)$, and avoided any significant increase in humidity. Arterial blood samples were taken during the final $2 \mathrm{~h}$ of the infusion for the assay of the specific radioactivity (SRA) of the infused substrate. The SRA of ${ }^{14} \mathrm{CO}_{2}$ in expired air was measured by bubbling the output from the diaferometer through an absorption tower containing $\mathrm{CO}_{2}$-free $0.5 \mathrm{M}-\mathrm{NaOH}$, and assaying the ${ }^{14} \mathrm{CO}_{2}$ as $\mathrm{Ba}^{14} \mathrm{CO}_{3}$.

Fatty-acid entry rates were calculated from the SRA achieved in plasma during the terminal stages of the infusion of known amounts of labelled substrate, as described by Annison, Brown, Leng, Lindsay \& West (1967). A rough estimate of the contribution of the substrate to $\mathrm{CO}_{2}$ production, and of the extent of substrate oxidation, was calculated from the SRA of ${ }^{14} \mathrm{CO}_{2}$ during the terminal stages of the infusion (Annison et al. 1967).

\section{Preparation of liver homogenates}

The liver was excised as rapidly as possible from birds killed by dislocation of the neck, and placed on ice. Six samples ( $2 \mathrm{~g}$ ) of tissue were minced with fine scissors and homogenized with $0.25 \mathrm{M}$-sucrose containing $5 \mathrm{mM}$-tris buffer (Dawson, Elliott, Elliott \& Jones, 1959) at $\mathrm{pH} 7 \cdot 4$ in a Teflon-glass homogenizer with the plunger rotating at $700 \mathrm{rev} / \mathrm{min}$ (plunger clearance $0.305 \mathrm{~mm}$ ). These portions were bulked and further homogenized (three strokes of the plunger) with $0.127 \mathrm{~mm}$ clearance between the plunger and the glass. The homogenate was centrifuged at $4^{\circ}$ for $20 \mathrm{~min}$ at $9000 \mathrm{~g}\left(r_{\mathrm{av} .}\right)$. The supernatant fraction was separated from the clot containing cell debris and mitochondria and centrifuged at $76000 \mathrm{~g}\left(r_{\mathrm{av}}\right.$.) for $\mathrm{I} \mathrm{h}$. A clear and a cloudy fraction were observed in the supernatant solution and were mixed before the assays. The microsomes were resuspended in $20 \mathrm{ml} 0.25 \mathrm{M}$-sucrose and 5 mM-tris and collected by centrifugation.

\section{Assay of acetyl-CoA carboxylase}

Acetyl-CoA carboxylase activity in the particle-free supernatant fraction was determined by measuring the incorporation of $\left[{ }^{14} \mathrm{C}\right]$ bicarbonate into non-volatile compounds (Martin \& Vagelos, I962).

The incubation vessel contained $80 \mu \mathrm{mol}$ triethanolamine buffer $(\mathrm{pH} 7 \cdot 4), \mathrm{r}^{\prime} 4 \mu \mathrm{mol}$ 2-mercaptoethanol, 1o $\mu \mathrm{mol}$ potassium citrate, $3.5 \mu \mathrm{mol}$ manganese chloride, $5 \mu \mathrm{mol}$ ATP, $0.3 \mu \mathrm{mol}$ acetyl-CoA, $7.4 \mu \mathrm{mol}$ potassium bicarbonate and $500 \mathrm{nCi}$ sodium $\left[{ }^{14} \mathrm{C}\right]$ bicarbonate (carrier-free). Particle-free supernatant fraction $(0.4 \mathrm{ml})$ was added just before the addition of a mixture of potassium bicarbonate and sodium $\left[{ }^{14} \mathrm{C}\right] \mathrm{bi}$ carbonate $(0.2 \mathrm{ml})$ to the stoppered tube. The gas phase was air and the total volume $3 \mathrm{ml}$. After incubating at $40^{\circ}$ for $15 \mathrm{~min}$ the reaction was stopped by adding $0.2 \mathrm{ml}$ 
$70 \%$ perchloric acid $(\mathrm{v} / \mathrm{v})$. Nitrogen was bubbled through the reaction mixture for ro min to remove free ${ }^{14} \mathrm{CO}_{2}$. The protein precipitate was spun down and $0.5 \mathrm{ml}$ of the supernatant fraction assayed for radioactivity. Control tubes contained all the reagents except ATP and acetyl-CoA.

The rate of incorporation of bicarbonate into non-volatile compounds was linear with respect to both time and protein concentration. Results were expressed as $\mathrm{nmol} \mathrm{HCO}_{3}$ incorporated/min per mg protein. The standard error of the assay was $3.8 \%$.

\section{Desaturase activity in the microsome fraction}

Desaturase activity was determined by measuring the conversion of labelled stearic and palmitic acids into oleic and palmitoleic acids respectively, as described by Bickerstaffe \& Annison (1969).

\section{Radioactive materials}

$\left[\mathrm{U}-{ }^{14} \mathrm{C}\right]$ palmitic, $\left[\mathrm{U}-{ }^{14} \mathrm{C}\right]$ stearic, $\left[\mathrm{U}-{ }^{14} \mathrm{C}\right]$ oleic, and $\left[\mathrm{U}-{ }^{14} \mathrm{C}\right]$ linoleic acids, $\left[\mathrm{I}^{14} \mathrm{C}\right]-$ palmitic acid and $\left[{ }^{[}-{ }^{14} \mathrm{C}\right]$ stearic acids and sodium $\left[{ }^{14} \mathrm{C}\right]$ bicarbonate were obtained from the Radiochemical Centre, Amersham.

\section{Statistical analysis of results}

In order to examine the relationships between plasma concentration and rates of entry and oxidation for each individual fatty acid, the regression equations were fitted and their significance was tested by the F-test (Draper \& Smith, 1966).

\section{Chemical methods}

Protein determination. The method of Gornall, Bardawill \& David (I949) was used to determine the protein content of the microsome and particle-free supernatant fractions.

Lipid extraction. Lipids were extracted from plasma and liver homogenates by a modification of the method of Folch, Lees \& Stanley (1957). To obtain absolute values for the free fatty acid (FFA) concentrations and triglyceride concentration, heptadecanoic acid, added as FFA and triglyceride, was used as an internal marker. Marker was added to the plasma of fed birds at concentrations of ${ }_{15} \mu \mathrm{g} / \mathrm{ml}$ (FFA) and $140 \mu \mathrm{g} / \mathrm{ml}$ (triheptadecanoin). Corresponding concentrations of marker for the plasma of starved birds were 30 and $40 \mu \mathrm{g} / \mathrm{ml}$ respectively. The FFA and triglyceride classes were separated and analysed as described by West $\&$ Rowbotham (I967).

\section{Assay of radioactivity}

All samples were assayed by liquid scintillation counting using a Packard 4000 Series Spectrometer. An external standard of ${ }^{226} \mathrm{Ra}$ was used to correct for quenching. FFA and chloroform-methanol extracts of infusion solutions were assayed in toluene containing $4 \mathrm{~g} \mathrm{2,5}$-diphenyl oxazole (PPO)/1. Barium carbonate (IO-50 mg) was finely ground and suspended in a thixotropic gel $(\mathrm{r} 5 \mathrm{ml}$ ) comprising finely divided silica (Aerosil; Nuclear Enterprises Ltd, Edinburgh) and a solution of $4 \mathrm{~g} / 1 \mathrm{PPO}$ in toluene ( $38 \mathrm{~g}$ Aerosil/1 toluene). 
Table 3. Plasma free fatty acid (FFA) concentration in chicks given a high-fat or low-fat diet, either fed or after $48 \mathrm{~h}$ starvation

Diet

High-fat

High-fat

Low-fat

Low-fat

SD/observation*

\section{Nutritional state}

Fed

Starved

Fed

Starved

No. of
observations
I I
ro
9
8

FFA
concentration
(mmol/1)
0.37
0.59
0.23
0.61
0.07

Triglyceride concentration (mg/l)

660

107

604

1 I $242 \cdot 96$

* The SE for each mean may be calculated from the SD/observation and the number of observations.

Table 4 . Effect of the level of dietary fat as plasma free fatty acid (FFA) composition in fed chicks and in chicks starved for $48 \mathrm{~h}$

\begin{tabular}{|c|c|c|c|c|c|}
\hline \multirow[b]{2}{*}{ Acid* } & \multicolumn{2}{|c|}{ Low-fat diet } & \multicolumn{2}{|c|}{ High-fat diet } & \multirow[b]{2}{*}{ SD/observation } \\
\hline & Fed & Starved & Fed & Starved & \\
\hline $14: 0$ & $3 \cdot 9$ & $1 * 7$ & $2 \cdot 2$ & 1.7 & 0.8 \\
\hline $16: 0$ & $36 \cdot 6$ & $34 \cdot x$ & $27 \cdot 3$ & $27 \cdot 6$ & $2 \cdot 9$ \\
\hline I6:I & $4 \cdot 0$ & $6 \cdot 8$ & $2 \cdot 5$ & $3 \cdot 3$ & $I \cdot I$ \\
\hline I 8:0 & 19.5 & $15^{\circ} \mathrm{O}$ & $17 \cdot 7$ & $I 4 \cdot I$ & $2 \cdot 5$ \\
\hline 18: I & $18 \cdot 2$ & 2977 & $2 I \cdot 4$ & $26 \cdot 1$ & $3 \cdot 2$ \\
\hline I $8: 2$ & II. 0 & $9 \cdot 8$ & $22 \cdot 7$ & $22 \cdot 2$ & $2 \cdot 8$ \\
\hline $18: 3$ & $3 \cdot 2$ & $1 \cdot 3$ & $4 \cdot 1$ & $3 \cdot \mathrm{I}$ & $\mathrm{I} \cdot 5$ \\
\hline Others & $3 \cdot 5$ & $1 \cdot 6$ & $2 \cdot 1$ & $\mathrm{I} \cdot 9$ & 0.8 \\
\hline No. of observationsf & 9 & 8 & Io & ro & \\
\hline
\end{tabular}

Samples from the acetyl-CoA carboxylase assays were made up to $\mathrm{I} \mathrm{ml}$ with distilled water, and added to $5 \mathrm{ml}$ of Triton X-Ioo (Lennig Chemicals Ltd, Jarrow-on-Tyne) in PPO in toluene (2 parts PPO in toluene: I part Triton $\mathrm{X}-\mathrm{IOO}, \mathrm{v} / \mathrm{v}$ ) before counting.

\section{RESULTS}

\section{Effect of diet on plasma FFA in fed and starved birds}

The concentration of plasma FFA was significantly lower $(P<0.05)$ in birds given the low-fat diet than in birds given the high-fat diet (Table 3 ), and rose considerably in both groups of birds during starvation. Plasma triglyceride concentrations were roughly similar in both groups of birds, and were lower in starved birds (Table 3 ). The composition of the FFA fraction was influenced by the diet in both fed and starved birds (Table 4 ), but these differences were less marked than in the plasma triglycerides (Table 5). The concentrations of linoleic acid in the plasma FFA and triglyceride fractions were appreciably higher in birds given the high-fat diet. Associated with this increase was a decrease in the proportion of saturated and mono-unsaturated fatty acids in the plasma triglycerides. 
Table 5. Effect of the level of dietary fat on plasma triglyceride composition in fed chicks and in chicks starved for $48 \mathrm{~h}$

\begin{tabular}{|c|c|c|c|c|c|}
\hline \multirow[b]{2}{*}{ Acid* } & \multicolumn{2}{|c|}{ Low-fat diet } & \multicolumn{2}{|c|}{ High-fat diet } & \multirow[b]{2}{*}{ so/observation } \\
\hline & Fed & Starved & Fed & Starved & \\
\hline $14: 0$ & $I^{\prime} 4$ & $I \cdot 6$ & $\mathrm{I} \cdot \mathrm{O}$ & $\mathrm{I} \cdot 8$ & 0.5 \\
\hline I6:0 & $35^{\prime} I$ & $28 \cdot 5$ & $20 \cdot 5$ & $26 \cdot 5$ & $2 \cdot 7$ \\
\hline I6:I & 4.3 & $3 \cdot 0$ & $I \cdot 9$ & $2 \cdot 4$ & 0.9 \\
\hline I 8:0 & $\mathrm{r} 3.5$ & 13.3 & $8 \cdot 6$ & $\operatorname{II} \cdot 7$ & $2 \cdot 7$ \\
\hline I8: 1 & $33 \cdot \mathrm{I}$ & $36 \cdot 8$ & $27 \cdot 2$ & $27 \cdot 0$ & $4 \cdot 4$ \\
\hline I $8: 2$ & 10.2 & $12 \cdot 8$ & $35 \cdot 2$ & $23 \cdot 9$ & $4 \cdot 2$ \\
\hline I $8: 3$ & $\mathbf{I} \cdot 2$ & $\mathrm{I} \cdot 5$ & 4.0 & 3.4 & $I \cdot 5$ \\
\hline Others $\uparrow$ & $I \cdot 2$ & $2 \cdot 4$ & 177 & $3 \cdot 3$ & 0.9 \\
\hline No. of observationst & 9 & 8 & Io & ro & \\
\hline
\end{tabular}

* Nomenclature according to Farquhar et al. (r959).

$\dagger 12: 0,13: 0,15: 0,20: 0$.

$\ddagger$ The SE for each mean can be calculated from the so/observation and the number of observations.

\section{Equilibrium of FFA and bicarbonate pools}

The SRA of the infused fatty acid in the plasma became constant within $2 \mathrm{~h}$. Constancy of the SRA expired $\mathrm{CO}_{2}$ was not achieved, however, although the plot of SRA against time roughly plateaued during the final $2 \mathrm{~h}$ of infusion. The terminal value was estimated graphically since insufficient results were obtained to allow calculation of the asymptotic value (see Annison et al. 1967).

\section{Metabolism of plasma, palmitate, stearate, oleate and linoleate}

About $85 \%$ of the plasma FFA of each group of chickens was accounted for as palmitic, stearic, oleic and linoleic acids (Table 4 ). The entry rates of each fatty acid, measured in two experiments are given in Table 6.

The entry rates of palmitic, stearic, oleic and linoleic acids were independent of the level of dietary fat, but were correlated with their concentrations in plasma. The regression equations relating the plasma concentration of each fatty acid to entry rate were:

Palmitic acid
Stearic acid
Oleic acid
Linoleic acid

$$
\begin{aligned}
& y=0.46+11 \cdot 94 x \\
& y=0.88+7 \cdot 64 x \\
& y=0.52+8 \cdot 14 x \\
& y=0.03+17 \cdot 92 x
\end{aligned}
$$

$F$ ratio
$25 \cdot 4$
$11 \cdot 1$
$23 \cdot 2$
$16 \cdot 8$$$
\begin{aligned}
\text { Probability } \\
P<0.01 \\
P<0.02 \\
P<0.01 \\
P<0.01
\end{aligned}
$$

where $y=$ entry rate $(\mathrm{mg} / \mathrm{min})$ and $x=$ concentration of the plasma FFA (mmol/1).

The regression equations obtained relating the plasma concentration of each fatty acid to its rate of oxidation were:

$\begin{array}{lccc} & & F \text { ratio } & \text { Probability } \\ \text { Palmitic acid } & y=-4 \cdot 19+69 \cdot 63 x & 15 \cdot 4 & P<0 \cdot 01 \\ \text { Stearic acid } & y=-1 \cdot 18+48 \cdot 06 x & 14 \cdot 8 & P<0 \cdot 01 \\ \text { Oleic acid } & y=-2 \cdot 56+85 \cdot 14 x & 179 \cdot 9 & P<0 \cdot 00 \mathrm{I} \\ \text { Linoleic acid } & y=-2 \cdot 77+108 \cdot 11 x & 30 \cdot 17 & P<0 \cdot 0 \mathrm{I}\end{array}$

where $y=$ contribution to $\mathrm{CO}_{2}(\%)$ and $x=$ concentration of the plasma FFA $(\mathrm{mmol} / \mathrm{l})$. 
Table 6. Effects of the level of dietary fat on the rates of entry and oxidation of palmitic, stearic, oleic and linoleic acids in plasma of fed chicks and of chicks starved for $48 \mathrm{~h}$

(The results of two experiments in each treatment are shown)

\begin{tabular}{|c|c|c|c|c|c|}
\hline $\begin{array}{l}\text { Fatty } \\
\text { acid }\end{array}$ & $\begin{array}{l}\text { Nutritional } \\
\text { status }\end{array}$ & $\begin{array}{l}\text { Dietary } \\
\text { fat level }\end{array}$ & $\begin{array}{l}\text { Fatty acid } \\
\text { concentration } \\
(\mathrm{mmol} / \mathrm{l})\end{array}$ & $\begin{array}{c}\text { Entry rate } \\
\left(\mathrm{mg} / \mathrm{min} \text { per } \mathrm{kg}^{0 \cdot 7 \bar{a}}\right)\end{array}$ & $\begin{array}{l}\text { Contribution to } \\
\mathrm{CO}_{2} \text { produced } \\
(\%)\end{array}$ \\
\hline \multirow[t]{6}{*}{ Palmitic } & Fed & Low & 0.092 & $1 \cdot 2$ & $1 \cdot 6$ \\
\hline & & & 0.090 & $I \cdot I$ & $x \cdot 5$ \\
\hline & Starved & Low & $\begin{array}{l}0.260 \\
0.168\end{array}$ & $\begin{array}{l}3 \cdot 3 \\
3.0\end{array}$ & $\begin{array}{r}14.5 \\
9.6\end{array}$ \\
\hline & Fed & High & 0.090 & $1 \cdot 9$ & $4 \cdot 9$ \\
\hline & & & 0.078 & $1 \cdot 5$ & $I \cdot 4$ \\
\hline & Starved & High & $\begin{array}{l}0.15 I \\
0.160\end{array}$ & $\begin{array}{l}2 \cdot 1 \\
2 \cdot 6\end{array}$ & $\begin{array}{r}10 \cdot 4 \\
8 \cdot 4\end{array}$ \\
\hline \multirow[t]{8}{*}{ Stearic } & Fed & Low & 0.042 & $I \cdot O$ & 0.4 \\
\hline & & & 0.019 & $I \cdot I$ & 0.4 \\
\hline & Starved & Low & 0.099 & $\mathrm{I} \cdot 8$ & $5 \cdot 7$ \\
\hline & & & 0.125 & $I \cdot 7$ & $4 \cdot 9$ \\
\hline & Fed & High & 0.074 & I. 2 & $1 \cdot 5$ \\
\hline & & & 0.017 & $r \cdot 6$ & 0.7 \\
\hline & Starved & High & 0.080 & $1 \cdot 7$ & 4.4 \\
\hline & & & 0.077 & $I \cdot 4$ & $2 \cdot 8$ \\
\hline \multirow[t]{8}{*}{ Oleic } & Fed & Low & 0.026 & 0.5 & 0.4 \\
\hline & & & 0.048 & 0.9 & 0.9 \\
\hline & Starved & Low & 0.206 & $I \cdot 9$ & I5.8 \\
\hline & & & 0.140 & $I \cdot 4$ & $7 \cdot 2$ \\
\hline & Fed & High & 0.060 & $I \cdot O$ & $2 \cdot 6$ \\
\hline & & & 0.042 & $I \cdot x$ & I.3 \\
\hline & Starved & High & $0.15^{\circ}$ & $I \cdot 8$ & II 4 \\
\hline & & & (1) & -4 & 122 \\
\hline \multirow[t]{7}{*}{ Linoleic } & Fed & Low & 0.057 & $I \cdot 4$ & $2 \cdot 9$ \\
\hline & & & 0.075 & $I \cdot 6$ & $3 \cdot 3$ \\
\hline & Starved & Low & 0.088 & $\begin{array}{l}I \cdot I \\
0.8\end{array}$ & $\begin{array}{l}6.1 \\
5.0\end{array}$ \\
\hline & Fed & High & 0.113 & $I \cdot 8$ & 10.5 \\
\hline & & & 0.126 & $2 \cdot 6$ & 12.9 \\
\hline & Starved & High & 0.150 & 2.5 & II'I \\
\hline & & & 0.120 & $2 \cdot 6$ & $x I \cdot 3$ \\
\hline
\end{tabular}

These equations suggest that at low concentrations of FFA in the plasma each acid contributes a nearly equal amount of $\mathrm{CO}_{2}$ at a given FFA concentration. However, when concentrations are increased, there is a higher contribution by oleic acid and, in particular, linoleic acid to the $\mathrm{CO}_{2}$ compared with that of palmitic or stearic acids.

The negative intercept value suggests that each estimate of the contribution of $\mathrm{CO}_{2}$ was an underestimate, since equilibrium was not reached during the experimental period and, as a result, terminal SRA $\mathrm{CO}_{2}$ values were underestimated.

\section{Effect of dietary fat intake on acetyl $\mathrm{Co} A$ carboxylase activity in fed birds}

The activity of acetyl-CoA carboxylase in the livers of birds fed on high-fat and low-fat diets was used as an index of the relative rates of lipogenesis in these birds. The activity in the mixed particle-free supernatant fraction was $0.28 \pm 0.02 \mathrm{nmol} / \mathrm{min}$ 


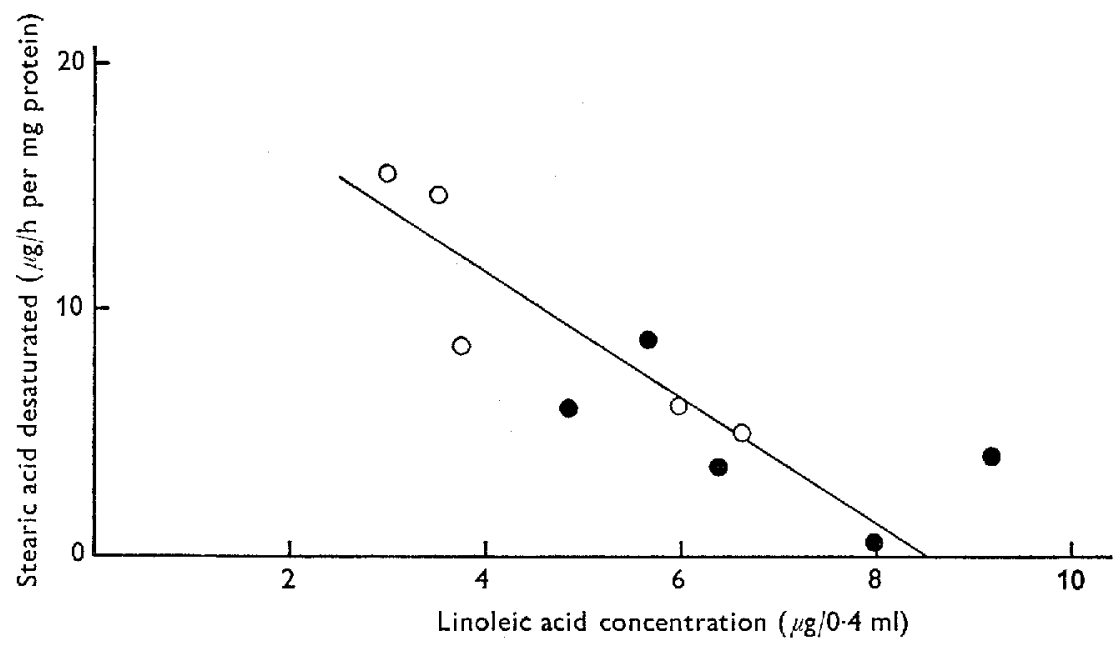

Fig. I. Effect of free linoleic acid concentration in liver homogenates from chicks fed on the low-fat $(O)$ and high-fat (O) diets on the desaturation of stearic acid.

per $\mathrm{mg}$ protein in nine birds fed on the low-fat diet and $0.16 \pm 0.01 \mathrm{nmol} / \mathrm{min}$ per $\mathrm{mg}$ protein in nine birds given the high-fat diet.

\section{Effect of dietary fat intake on desaturase activity in fed birds}

The extent of desaturation of added labelled stearic acid was significantly greater $(P<0.01)$ in the liver of the five birds fed on the low-fat diet than in birds fed on the high-fat diet. In the former $28 \cdot 8 \pm 4.5 \%$ of this acid was converted into oleic acid compared with $\mathrm{x} \cdot 8 \pm 2.4 \%$ in the latter.

The FFA associated with the microsomal fraction was extracted with chloroform in methanol $(2: \mathrm{I}, \mathrm{v} / \mathrm{v})$. An inverse linear relationship was observed between the desaturase activity and the concentration of the free linoleic acid (Fig. I). No correlation was observed between either the total FFA or the total unsaturated FFA concentration and the rate of desaturation.

\section{DISCUSSION}

Isotope dilution techniques have revealed small differences in the metabolism of palmitic, stearic, oleic and linoleic acids in young chickens. The rates of entry and oxidation of the fatty acids in fed and starved $(48 \mathrm{~h})$ birds were well correlated with their concentrations in plasma, but the unsaturated acids, oleic and linoleic acids, made a greater contribution to oxidative metabolism than the saturated acids at raised levels of plasma FFA. As in other species, plasma FFA concentrations were inversely correlated with nutritional status (see Annison, I97r), although the concentrations in fed birds receiving the high-fat diet were significantly higher than those in birds fed on the low-fat diet (Table 3 ).

Plasma triglyceride concentrations in fed and starved $(48 \mathrm{~h})$ birds were not affected by the level of dietary fat. The main sources of plasma triglyceride in the bird are 
dietary fat, which in the absence of lymphatic absorption enters the portal system as low-density lipoproteins, and the liver, which is the major site of lipogenesis (see Annison, 1971). The similarity in plasma triglyceride concentration observed between the high-fat and low-fat birds suggested that hepatic lipogenesis was likely to be higher in the latter group. The higher acetyl-CoA carboxylase activity in the livers of the birds fed on the low-fat diet was in line with this view. Pearce (1968) observed a reduction in the acetyl-CoA carboxylase activity of the liver of hens transferred from a low-fat diet to a high-fat diet.

Liver desaturase activity in the birds on the high-fat diet was roughly half of that of those on the low-fat diet. Inkpen et al. ( 1969 ) showed that low-fat diets stimulated desaturase activity in rats, and that the reduction in activity resulting from high-fat diets was largely due to increasing intakes of linoleic acid. In the present studies the high-fat diets were rich in linoleic acid, and it was not possible to distinguish between the effect of a high intake of fat and that of the increased intake of linoleic acid. As in the rat, free linoleic acid inhibited the desaturation of stearic acid (Fig. I). Desaturase activity was not directly correlated with the total FFA concentration in the assay medium, or with the concentration of unsaturated FFA.

Comparison of the SRA of circulating ${ }^{14} \mathrm{C}$-labelled fatty acid and expired ${ }^{14} \mathrm{CO}_{2}$ during the final stages of the fatty acid infusions allowed the contribution of the individual fatty acid to total $\mathrm{CO}_{2}$ production to be roughly assessed. The procedure cannot over-estimate fatty acid oxidation, but in some instances the retention of ${ }^{14} \mathrm{CO}_{2}$ in slowly equilibrating body pools will result in underestimates of the contribution of fatty acid to $\mathrm{CO}_{2}$ output (see Annison et al. ${ }_{1967)}$ ). The total contributions to $\mathrm{CO}_{2}$ of palmitate, stearate, oleate and linoleate in fed and starved $(48 \mathrm{~h})$ birds on the low-fat diet were 6 and $35 \%$ respectively; corresponding values for birds given the high-fat diet were in line with the higher total plasma FFA concentrations (Table 3).

The rates of entry and oxidation of linoleate relative to those of the other major fatty acids suggested the absence of special mechanisms for the sparing of this essential fatty acid (EFA). In the low-fat diet the level of linoleate $(9 \mathrm{~g} / \mathrm{kg}$ ) was somewhat below the recommended level ( $13 \mathrm{~g} / \mathrm{kg}$ ) for maximum growth (see Hathaway, I968). No evidence of EFA deficiency was observed, but any unique feature of linoleate metabolism impinging on its rates of entry or oxidation might have been expected to show up under these conditions.

\section{REFEREN CES}

Annison, E. F. (197I). In Physiology and Biochemistry of the Domestic Fowl Vol, I, p. 321 [D. J. Bell and B. M. Freeman, editors]. London and New York: Academic Press.

Annison, E. F., Brown, R. E., Leng, R. A., Lindsay, D. B. \& West, C. E. (1 967). Biochem. F. 104, 135.

Balnave, D. \& Pearce, J. (1969). Comp. Biachem. Physiol. 29, 539.

Bickerstaffe, R. \& Annison, E. F. (1969). Biochem. F. I1 1 , 49.

Bortz, W., Abraham, S. \& Chaikoff, I. L. (1963). \%. biol. Chem. 238, 1266.

Dawson, R. M., Elliott, D. C., Elliott, W. M. \& Jones, K. M. (1959). Data for Biochemical Research. Oxford: Clarendon Press.

Draper, N. \& Smith, H. (1966). Applied Regression Analysis p. 16. New York: John Wiley.

Farquhar, J. W., Insull, W. Jr, Rosen, P., Stoffel, W. \& Ahrens, E. M. Jr (1959). Nutr. Rev. 17, suppl. no. 8.

Folch, J., Lees, M. \& Stanley, G. H. S. (1957). F. biol. Chem. 226, 497. 
Goodridge, A. G. \& Ball, E. G. (Ig66). Am. F. Physiol. 2rr, 803.

Gornall, A. G., Bardawill, C. J. \& David, H. M. (1949). F. biol. Chem. 73, 75 r.

Hathaway, H. D. (1968). In Proceedings of the University of Nottingham School of Agriculture Second Nutrition Conference for Feed Manufacturers p. 22 [H. Swan and D. Lewis, editors]. London: J. \& A. Churchill.

Inkpen, C. A., Harris, R. A. \& Quakenbush, F. W. (1969). 7. Lipid Res. 10, 277.

Laurell, S. (1957). Acta physiol. scand. 4I, ${ }_{5} 8$.

Martin, D. B. \& Vagelos, P. R. (1962). $\%$. biol. Chem. 237, i 787.

Pearce, J. (1968). Biochem. F. rog, 702.

West, C. E. \& Rowbotham, T. R. (I967). F. Chromat. 30, 62. 